\title{
Similar biotherapeutic products in Latin America. Regulation and opportunities for patients with autoimmune diseases
}

This article was published in the following Dove Press journal:

Biosimilars

3 January 2013

Number of times this article has been viewed

\author{
Zayrho Desanvicente-Celis \\ Julian Caro-Moreno \\ Mateo Enciso-Zuluaga \\ Juan-Manuel Anaya
}

Center for Autoimmune Diseases Research (CREA), Universidad del Rosario, Bogotá, Colombia
Correspondence: Juan-Manuel Anaya Center for Autoimmune Diseases Research (CREA), School of Medicine and Health Sciences, Universidad del Rosario, Carrera 24, 63-C-69, third floor, Bogotá, Colombia Tel +57 I 3499650

$\mathrm{Fax}+57$ I 3499340

Email juan.anaya@urosario.edu.co

\begin{abstract}
Biotherapeutic products have revolutionized medicine, changing the way we can treat some chronic diseases, such as autoimmune diseases. The patent expiry and the high costs of reference biotherapeutic products, among other factors, have promoted interest in similar biotherapeutic products (SBPs), also known as biosimilars. The objective of developing an SBP is to manufacture a "highly similar" molecule to a reference biotherapeutic product, by conducting a comparability exercise that can demonstrate similar quality, safety, and efficacy. Regulations like those of the World Health Organization, the European Medicines Agency, and the Food and Drug Administration are international reference standards. Herein, we aim to point out the current status in Latin America on SBPs, focusing on regulatory issues within the context of autoimmune diseases. The regulations of Argentina, Peru, Chile, Guatemala, Panama and Costa Rica follow the World Health Organization guidelines. Other countries, such as Cuba, Mexico, Venezuela, and Brazil have regulations that take into account international standards combined with local features. In Colombia, a draft decree is under revision and the debate is ongoing. Some countries have already approved SBPs. Mexico, Chile, Ecuador, Bolivia, and Peru market SBPs of rituximab, and Colombia markets an SBP of etanercept. The advent of SBPs is definitely beneficial. Safety and efficacy must be ensured following clear and comprehensive regulations.
\end{abstract}

Keywords: biological therapy, biotechnology, similar biotherapeutic product, autoimmune disease, Latin America

\section{Introduction}

Biotechnology is a growing field within the health sciences that allows the development of new effective therapeutic products. ${ }^{1,2}$ Biotherapeutic products (BPs) have revolutionized modern medicine, introducing new molecules that have changed the way we can treat autoimmune diseases (ADs) and other chronic conditions. ${ }^{3-5}$ This revolution has opened optimistic scientific perspectives in a scenario of epidemiological transition from infectious to chronic diseases. ${ }^{6}$ Nevertheless, the production and supply of BPs are a challenge for governments and modern health systems, given the elevated costs and the limited access to these therapies, especially in developing countries. ${ }^{4}$ The recent advent of similar biotherapeutic products (SBPs) has raised much controversy worldwide, because of the implications related with their regulation and subsequent entry to market, and all the different interests of the different parties affected. This is why much attention is currently given to the regulations concerning BPs and SBPs.

BPs are mostly large recombinant proteins derived from life forms. ${ }^{3,5}$ Commercially available BPs include insulin, human growth hormone, erythropoietin, granulocyte 
colony-stimulating factor, interferon- $\alpha$, and monoclonal antibodies (mAbs), among others. ${ }^{2,7}$ SBP has been defined by the World Health Organization (WHO) as a biotherapeutic products that is similar in terms of quality, safety, and efficacy to an already-licensed reference biotherapeutic product (RBP). ${ }^{4}$ A variety of terms have been used to mention these products, including the term "biosimilars." ${ }^{4,8-14}$ There is some controversy regarding the proper term for designating these products. What has been highlighted is the fact that all these terms should not be used as synonyms of "generics," and that the term "biogeneric" is currently obsolete. ${ }^{15,16}$ For the present manuscript, the term SBP(s) will be used to designate biosimilar(s). Relevant definitions used throughout the present manuscript are disclosed in Table 1.

BPs are different from conventional pharmaceuticals in three important aspects: (1) high-complexity manufacturing process (MP), (2) active substances of more structural complexity and larger molecular size, especially in the case of mAbs, and (3) BPs are more likely to induce immunogenicity than conventional medications. Details pertaining to the development of a SBP are beyond the scope of this manuscript and can be consulted elsewhere..$^{1,2,5,17}$ In the MP of BPs, once the protein has been sequenced, recombinant DNA biotechnology permits the production of the molecule on a large commercial scale. ${ }^{2}$ The steps of the MP are: (1) cloning and protein expression, (2) protein production, and (3) purification and validation. Quality control for the confirmation of the DNA sequence of the cloned gene is usually conducted before and after full-scale fermentation. The process ends with the characterization and stability of the purified bulk drug. Additional activities within the MP are those related to storage and handling. ${ }^{9}$

The main objective in the development of an SBP is to manufacture a molecule that can be "highly similar" to the RBP. ${ }^{18}$ It is known that RBPs undergo changes over time. These changes provide a distribution of attributes that can be considered acceptable because the product has been administered to patients successfully. ${ }^{18}$ The limits to this distribution of the RBP attributes are denominated "goalposts." 18 These predefined limits of variability (goalposts) can be used as a starting point for comparing SBPs with RBPs. If the attributes of an SBP fall within the variability limits accepted for the RBP, then the SBP can be considered "highly similar" to the RBP. ${ }^{18}$ In the development of generic pharmaceuticals, only the chemical structure has to be reproduced. In this case, demonstration of structural similarity and bioequivalence is usually enough to demonstrate therapeutic equivalence. ${ }^{2,4}$ However, the generic approach is not suitable for licensing SBPs. ${ }^{4,16}$ For that reason, a comprehensive comparability exercise (CE) must be conducted, with the objective of establishing similarity in quality, safety, and efficacy. Products should be compared in the same study using the same procedures. ${ }^{4}$ Within the CE, there are different levels of comparability: quality evaluation (ie, physicochemical and biological characterization, immunochemical properties, and impurities) and nonclinical and clinical evaluation (Figure 1). ${ }^{17,18}$ The nonclinical evaluation comprises the pharmacotoxicological assessment of the SBP, involving in vitro and in vivo studies. ${ }^{4,19}$ The establishment of safety and efficacy profiles of the SBP usually requires some nonclinical data. The purpose of the clinical evaluation is to demonstrate comparable safety and efficacy of the SBP with the RBP. This evaluation is a stepwise procedure that begins with pharmacokinetic (PK) and pharmacodynamic (PD) studies followed by clinical efficacy and safety trial(s). ${ }^{4,19}$ Given that BPs are biologically active molecules that are capable of inducing immune responses, immunogenicity is an important consideration within the evaluation of safety. ${ }^{2,4}$ In the clinical evaluation, similar efficacy between the SBP and the RBP should be demonstrated in adequately powered, randomized, and controlled clinical trial(s), preferably doubleblind or at least observer-blind. ${ }^{4}$ For this purpose, equivalence trials (ETs) requiring lower and upper comparability margins are clearly preferred for the comparison of efficacy and safety, as requested by the guidelines of the European Medicines Agency (EMA). ${ }^{4,16}$ However, noninferiority trials (NITs), which require only one margin, may be considered if appropriately justified. ${ }^{4}$ Details on the methods and the levels of the CE can be consulted elsewhere and are well described in the guidelines on SBPs of the WHO. ${ }^{1,4,19}$ Additionally, pharmacovigilance programs are a fundamental issue that must be defined for the approval of every BP.

BPs represent one of the fastest-growing sectors of the pharmaceutical industry. ${ }^{2,20}$ Approximately 30\% of pharmaceutical and biotechnology research and development is composed of BPs, and nearly a third of this is related to mAbs. ${ }^{18}$ However, the growth of this industry is parallel with the cost that health systems must pay for it. Presently, some phenomena promote interest in SBPs, such as the rapid growth of the biotechnology market and the great lucrative potential of this industry, the expiry of the patents of RBPs, the high costs associated with the commercialization and usage of RBPs, the imperious need of governments and health systems for cost containment and better access to these medicines, and the establishment of regulatory frameworks that favor the entry to market of SBPs. ${ }^{2,5,18,20}$ 


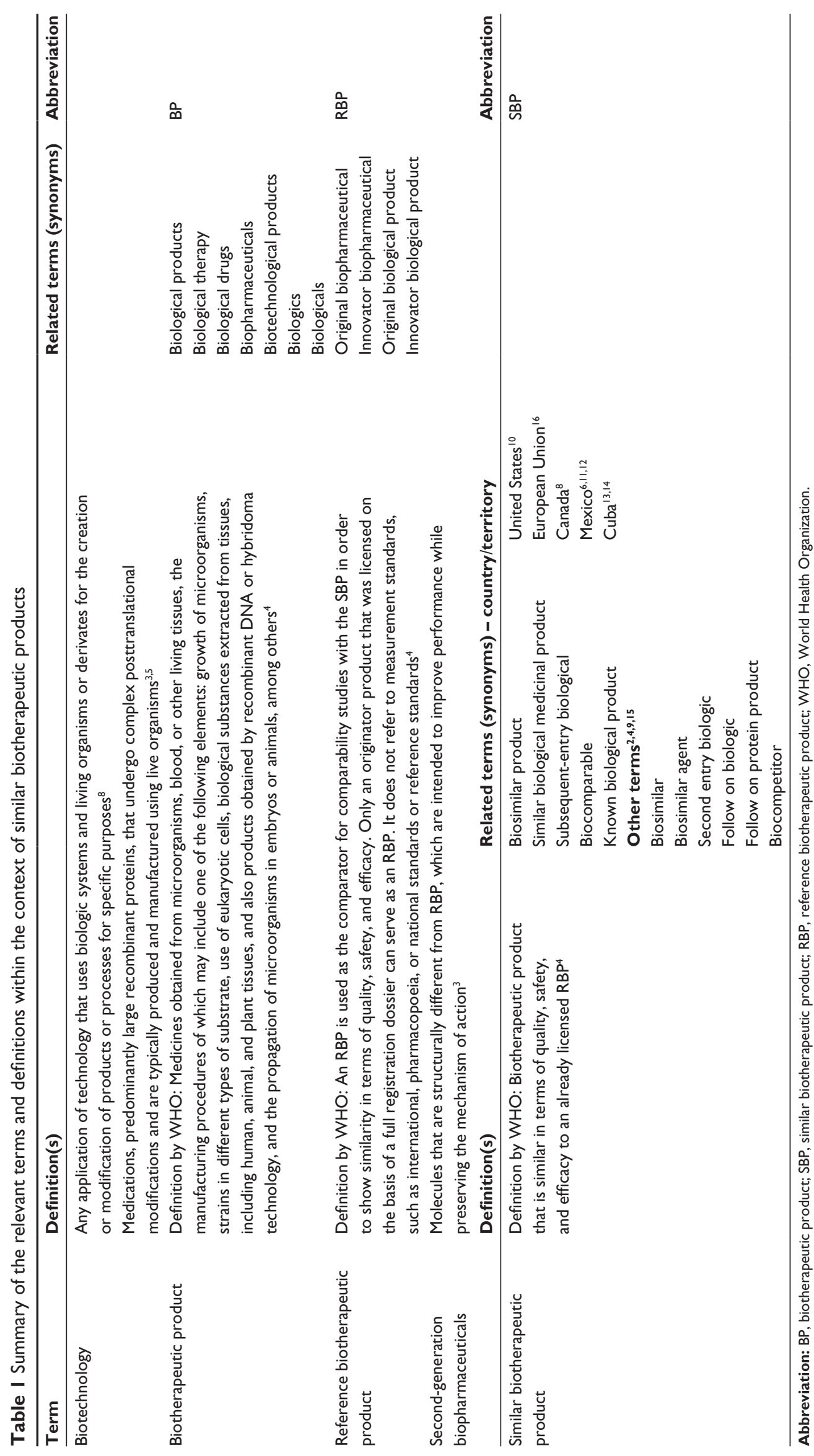




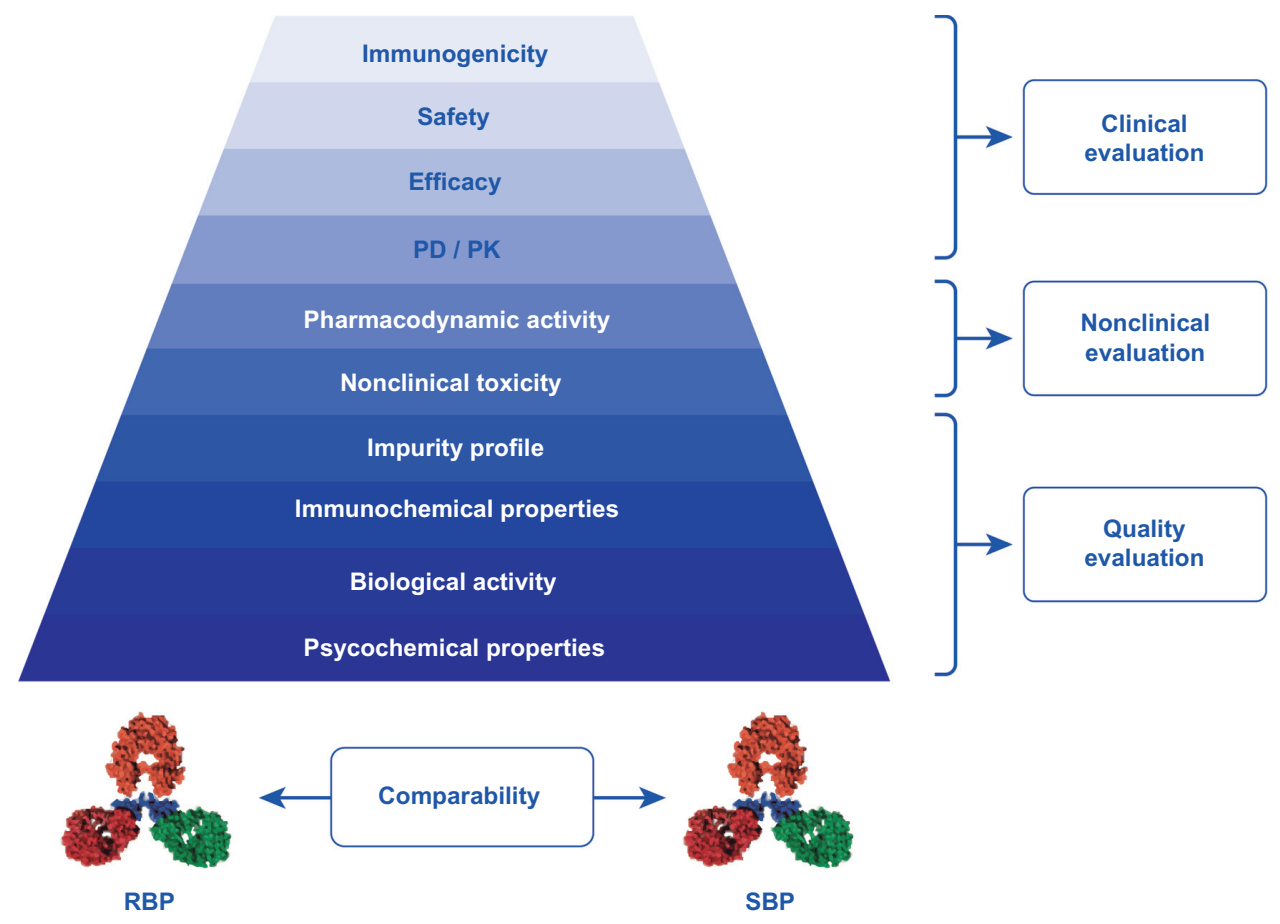

Figure I Comparability exercise.

Abbreviations: SBP, similar biotherapeutic product; RBP, reference biotherapeutic product; PK, pharmacokinetics; PD, pharmacodynamics.

Herein, we aim to point out the current status in Latin America (LA) of SBPs, focusing on regulatory issues within the context of ADs, chronic and potentially life-threatening conditions of increasing public health concern. Emerging information regarding molecular and cellular mechanisms about the physiopathology of ADs has identified many potential targets for the treatment of these common conditions. In diseases such as rheumatoid arthritis (RA), systemic lupus erythematosus, and vasculitis, available BPs are fundamental within the available therapeutics, having an important role in reducing disease progression and improving working productivity and quality of life. ${ }^{21,22}$ Despite these benefits, BPs have a high unit cost and are often used for chronic conditions like ADs that require ongoing treatment, representing significant expenditures for health budgets. ${ }^{23,24}$ The industry of biotechnology and SBPs has raised the interest of many pharmaceutical companies and stakeholders worldwide. Currently, biotechnology companies in Asia, Europe, and Israel are developing SBPs of tumor necrosis factor (TNF) inhibitors, B-cell depletion molecules such as rituximab (RTX), and selective costimulation modulators such as abatacept. ${ }^{3}$ SBPs of RTX are being marketed in India and some LA countries (Table 2). SBPs have not been approved yet for RA or systemic lupus erythematosus in the European Union (EU) or the United States (US). ${ }^{25,26}$ However, due to all the known characteristics and important benefits, availability of SBPs in the US and EU is anticipated not only to enhance competition and create better patient access to biotechnology products but also to lower their cost.

\section{Literature review}

After a literature search conducted on PubMed, Embase, Scopus, Lilacs, Scielo, and Biblioteca Virtual en Salud, 18 full-text documents were selected. Inclusion criteria were the following: general documents regarding the situation, perspectives and regulations of SBPs in LA countries, and specific documents related to biotechnology and SBPs in the context of autoimmune rheumatic diseases. Exclusion criteria included topics other than the aforementioned and documents in languages that were not English or Spanish. The chosen documents included reviews, editorials, perspectives, reflections, commentaries, and letters to the editor, amongst others.

Additionally, other sources were manually searched, most corresponding to legislative and regulatory documents, and in some cases newspaper articles. The official government websites of LA countries were consulted, looking for approved SBPs as well as for specific regulations on BPs and/or SBPs. ${ }^{12,14,27-60}$ The websites of ministries of health or equivalent institutions were also consulted, as were the 
Table 2 Approved SBPs in the context of autoimmune rheumatic diseases and state of the regulations on SBPs in Latin America

\begin{tabular}{|c|c|c|}
\hline Country & SBPs approved & $\begin{array}{l}\text { Specific regulation } \\
\text { on } \mathrm{SBPs}^{\mathrm{a}}\end{array}$ \\
\hline Mexico & Kikuzubam (RTX) $(2010)^{b}$ & Available \\
\hline Cuba & No & Available \\
\hline Dominican & Not found & Not found \\
\hline \multicolumn{3}{|l|}{ Republic } \\
\hline Puerto Rico & Not found & Not found \\
\hline Haiti & Not found & Not found \\
\hline Guatemala & No & Available \\
\hline Honduras & Not found & Not found \\
\hline El Salvador & No & Not found \\
\hline Nicaragua & No & Not found \\
\hline Costa Rica & No & Available \\
\hline Panama & Not found & Available \\
\hline Colombia & Etanar (ETN) (2006) & Available \\
\hline Venezuela & No & Available \\
\hline Ecuador & Reditux (RTX) (20I2) & No \\
\hline Peru & Reditux (RTX) & Available \\
\hline Brazil & Not found ${ }^{c}$ & Available \\
\hline Bolivia & Reditux (RTX) (2009) & Available \\
\hline Paraguay & Not found & Not found \\
\hline Uruguay & Not found & Not found \\
\hline Chile & Reditux (RTX) (20I0) & Available \\
\hline Argentina & No & Available \\
\hline
\end{tabular}

Notes: aSee text for details. In the case of Colombia, regulation is still under review; bthe year of approval appears in parentheses; in the case of Peru, this information was not available. Official governmental websites were consulted, looking for approved SBPs and specific regulations on BPs and/or SBPs in all the Latin American countries; ${ }^{12,14,27,59}$ the official Brazilian website was consulted, but the registries of BPs used in rheumatic diseases could not be viewed. ${ }^{60}$

Abbreviations: SBPs, similar biotherapeutic products; RTX, rituximab; ETN, etanercept; BPs, biotherapeutics products.

websites and databases of public consultation of the authority responsible for drug regulation in each country. Although the latest and most relevant information found is presented in this manuscript, legislation on the matter and approval of SBPs concerns issues that are constantly changing. Additionally, current regulations may be modified, amended, or supplemented at any time by the relevant authorities of each country.

\section{Regulatory background}

The first regulatory body in constructing guidelines was the EMA. In 2005, the first official document on the matter was published. ${ }^{16}$ In 2006, complementary guidelines on quality issues and nonclinical and clinical issues were published. ${ }^{19,61}$ In 2007, a complementary guideline on immunogenicity assessment was enacted.$^{62}$ Additionally, the EMA has published specific guidelines for each type of medication. ${ }^{63}$ So far, SBPs of growth hormone, erythropoietin, and granulocyte colony-stimulating factor have been approved in the EU. ${ }^{25}$ For the approval of an SBP, quality, nonclinical, and clinical studies are required by the EMA; in the case of clinical trials, ETs are requested..$^{16,19,64}$ Currently, the overarching guideline of the EMA that was enacted in 2005 and the guideline enacted in 2006 about nonclinical and clinical issues are under revision, with the aim of actualizing these documents and discussing in detail some relevant aspects like the terminology regarding SBPs, aspects on the equivalence of efficacy and safety, the possible reduction of the number of animal experiments, the selection of relevant PK markers, recommendations of patient population within pivotal phase III clinical trials, extrapolation of indications, and alternatives to the equivalence design in clinical trials, among other aspects. ${ }^{64,65}$ The draft revision 1 of the EMA guideline on quality issues that was enacted in 2006 is now available. ${ }^{66}$ In May 2012, a guideline on nonclinical and clinical aspects regarding mAbs was published by the EMA. ${ }^{67}$ This guideline recommends a stepwise approach, where the extent and the nature of the nonclinical and clinical evaluation depend on the level of evidence obtained in the previous step. ${ }^{67} \mathrm{~A}$ case-by-case basis is recommended for nonclinical evaluation to decide the choice and the extent of in vitro and in vivo studies; the necessity of in vivo studies is determined by in vitro studies. ${ }^{67} \mathrm{~A}$ comparative PK study is the first step in $\mathrm{mAb}$ clinical evaluation. PK data can be helpful to extrapolate data on efficacy and safety between different clinical indications of the reference $\mathrm{mAb}$. If dosecomparative and highly sensitive PD studies cannot be performed convincingly showing comparability in a clinically relevant manner, similar clinical efficacy between the SBP and the RBP should be demonstrated in adequately powered, randomized, parallel-group comparative clinical trial(s), preferably double-blind, normally ETs. ${ }^{67}$

In the US, the Patient Protection and Affordable Care Act of 2010 (Public Law no 111-148), through section 7002 of the act, which is known as the Biologics Price Competition and Innovation of 2009 (BPCI Act), amended the creation of an abbreviated approval pathway for the evaluation of SBPs shown to be biosimilar to or interchangeable with an RBP. ${ }^{10,68}$ In February 2012, the Food and Drug Administration (FDA) issued draft guidance for the industry on the implementation of the BPCI Act approval process for SBPs. These included scientific and quality considerations in demonstrating biosimilarity to a reference protein product. ${ }^{10,69}$ In these guidelines, the FDA intends to consider the totality of the evidence provided by a sponsor to support a demonstration of biosimilarity, and recommends sponsors use a stepwise approach in their development of SBPs. ${ }^{10}$ The FDA stated that the totality-of-the-evidence approach will be used to review 
applications for SBPs. Biosimilarity refers to the fact that the SBP and the RBP “... are highly similar notwithstanding minor differences in clinically inactive components and that there are no clinically meaningful differences between the two products in terms of safety, purity, and potency." 10 The clinical evaluation must include a clinical study/studies (including assessment of immunogenicity and PK or PD) sufficient to demonstrate safety, purity, and potency in one or more appropriate conditions of use for which the RBP is licensed. ${ }^{10}$ It was stated that: "The scope and magnitude of clinical studies will depend on the extent of residual uncertainty about the biosimilarity of the two products, after conducting structural and functional characterization and possible animal studies." 10 A sponsor of an SBP must provide justification for the proposed clinical study design. In the draft guideline, some facts that can influence the choice of the design are stated, as well as some specifications and discussion about ETs and NITs. ${ }^{10}$

In 2009, the WHO published the document Guidelines on Evaluation of Similar Biotherapeutics Products (SBPS). This document was intended to provide guidance to the different national regulatory authorities (NRAs) for the development of evaluation of such products, helping in the harmonization of the requirements worldwide, leading to greater ease and speed of approval and assurance of quality, effectiveness, and security. ${ }^{4}$ The WHO recognizes that some issues like intellectual property matters, interchangeability and substitution of RBPs with SBPs, and labeling and prescribing information need to be defined by NRAs. ${ }^{4}$ This document recommends quality, nonclinical, and clinical (ETs preferred) evaluation within the CE. ${ }^{4}$ The guidance of the WHO can be adopted as a whole or partially by NRAs, or used as a basis for establishing national regulatory frameworks, taking into account that some aspects must be defined locally according to the particular context. ${ }^{4,70}$

\section{Similar biotherapeutic products in Latin America}

In LA, ten countries have current specific regulations concerning the approval of SBPs: Mexico, Cuba, Guatemala, Costa Rica, Panama, Venezuela, Peru, Brazil, Chile, and Argentina. All these regulations have been published in the last 6 years. In Colombia, a second version of a draft decree that is under revision was published in May 2012. ${ }^{46}$ The principal characteristics of the WHO, EMA, FDA, and LA regulations are illustrated in Table 3. To our knowledge, specific regulations or drafts concerning SBPs have not been published in the rest of LA. Countries like Guatemala,
Costa Rica, Panama, Peru, Chile, and Argentina $35,42,44,51,57,59$ follow and/or consider international accepted standards like those of the WHO, FDA, and EMA guidelines. ${ }^{4,10,16,19}$ Mexico, Cuba, Venezuela, and Brazil have regulations that consider international standards in combination with local features. ${ }^{12,14,48,52,71}$ In the Brazilian case, although the regulation addresses the needs of the country, the scientific principles are based on the WHO guideline. ${ }^{71}$ In Peru, Ecuador, Chile, and Mexico, SBPs of RTX are currently available: Reditux, an SBP produced by the Indian manufacturer Dr Reddy's Laboratories, is approved in Peru, Ecuador, Bolivia, and Chile, and Kikuzubam, an SBP manufactured by the Mexican company Probiomed, has been commercialized in Mexico since 2010. ${ }^{27,50,72}$ In Colombia, Etanar, an SBP of etanercept (ETN) has been approved since 2006. ${ }^{45}$ However, this SBP was approved before the publication of a regulatory decree, as was Reditux in Ecuador and Chile. ${ }^{45,46,57,72}$ The results of the comprehensive search on SBPs approved in LA and on LA regulations on SBPs are shown in Table 2.

The Pan American Health Organization (PAHO) has been conducting efforts for the harmonization of the regulations on BPs and SBPs in LA and the Caribbean, through specific main objectives: (1) compilation of regulations on the matter in the member states, (2) establishment of a glossary that can facilitate the further development of related documents, (3) identifying regional documents for an appropriate elaboration of guidelines in the short and medium term, (4) establishing related issues, and (5) conducting working plans and developing tools and training programs for NRAs in relation to the regulatory oversight of BPs and related matters. ${ }^{73,74}$ In 2009, Pombo et al studied the state of the regulations of BPs in LA and the Caribbean for that year, through the development of surveys directed to the NRAs of the member countries of the PAHO. ${ }^{74}$ They found that $75 \%$ of the countries surveyed had regulations in place for BPs; however, there were no differences in these regulations for licensing different types of BPs, such as SBPs. Additionally, they found that few countries provided specific definitions for BPs and SBPs. ${ }^{74}$ The authors stated that "Although there was a great interest on the part of the countries surveyed in having harmonized documents for the licensing of BPs, there was no clear trend in the acceptance of mutual recognition mechanisms as an alternative to the licensing of BPs by countries that do not have a strong enough infrastructure for this purpose, without undermining the fact that such recognition must be established by each government and in some cases by partnerships between territories such as Mercosur, the Central American Customs Union, the Andean Community of Nations, the Alba, among others." ${ }^{74}$ 


\section{Mexico}

This nation has been at the forefront of innovation and biotechnology, assuming a leadership role in LA in the matter of regulation of BPs. ${ }^{6,11}$ In 2007, several forums and discussion about SBPs were developed within the Mexican Congress, a process that ended in 2009 with the amendment of article 222 Bis to the General Health Law, which established the general basis for the approval and marketing of SBPs. ${ }^{6,11,75}$ In 2010, Boardman, a Mexican senator and chairman of the health committee of the state of Coahuila, wrote an article in which he described the negotiation and regulation pertaining to BPs and SBPs in Mexico, highlighting the country for being at the vanguard, with legislation that ensures efficacy and safety, allows adequate availability and access, permits competition among manufacturers, leading to price reduction, and fosters the development of biotechnology. ${ }^{11}$ In 2011 , additional dispositions on the previous regulation on BPs and SBPs were incorporated by the Mexican government (Table 3). ${ }^{12}$ At the beginning of 2012, the Federal Commission for the Protection against Sanitary Risks announced actualizations on the regulations on BPs and SBPs. ${ }^{76,77}$ On the other hand, Mexico has been heading the manufacturing of SBPs in LA. The foundation Probiomed developed the SBP of RTX (Kikuzubam), which is already being marketed in Mexico, and plans to penetrate other markets..$^{27,77,78}$ However, the commercialization of this SBP has not been without controversy. ${ }^{77,79}$ Probiomed is also developing SBPs of other products like beta-interferon and filgrastim, among others, positioning and contributing to the economic growth of the country in this field. ${ }^{9,78,80}$

\section{Cuba}

This country has developed a pharmaceutical industry capable of responding to the needs of its national health system. ${ }^{13}$ The national industry is regulated by the Center for the Control of the National Quality of Medications (CECMED), which has faced the challenge of regulating a national industry with great scientific and high innovative potential and is dealing currently with the approval of SBPs locally manufactured. ${ }^{13}$ Science parks (SPs) are scientific organizations that link science, manufacturing, and services together. In the case of Cuba, the SP of western Havana brings together various institutions on the basis of a closed-loop strategy, covering all stages of research, development, production, and marketing of a pharmaceutical product. ${ }^{13}$ This SP has sustained important growth in Cuban scientific and technological activity, leading to the development and exportation in some cases of products such as vaccines, cytokines, and mAbs, among others.
Until October 2010, 133 BPs had been licensed in Cuba, of which 67 were locally manufactured. ${ }^{13}$ The basis for marketing authorization for medicines is based on the ministerial resolution "Rules for marketing authorization of medicinal products for human use," which classifies medications into categories according to their degree of novelty, where BPs corresponded to category A. ${ }^{13}$ After several years of following this classification, CECMED identified the need to redesign it, taking into account quality, safety, and efficacy, as well as time in the market and therapeutic effects of the product. ${ }^{13}$ As a result, the rules of marketing authorization were updated in 2009, reclassifying medications as follows: class 1 (A and B) for new medicinal products, and class 2 (C) for known medicinal products. ${ }^{13}$ The first draft of the Cuban guideline was released for consultation in $2010 .{ }^{13}$ In 2011, the definitive guidelines and requirements were published (Table 3).$^{14}$ In the context of mAbs, only the RTX innovator MabThera has been approved in Cuba for utilization in cancer; none of the BPs used in ADs is currently marketed as RBP or SBP for this indication. ${ }^{13,28}$

\section{Colombia}

The definitive regulation on the approval process of SBPs is under development. In January 2012, the first draft decree was presented and socialized by the Ministry of Health and Social Protection. ${ }^{81}$ After receiving opinions and comments on this decree by the different parties, on May 24, 2012, the Ministry of Health and Social Protection presented the second version of the draft decree, inviting the different parties to analyze and comment on this document (Table 3). ${ }^{46,82}$ However, the regulations and entry to market of SBPs have generated numerous biased debates. ${ }^{83-86}$

In 2006, Etanar, an SBP of ETN, was approved in Colombia for the treatment of RA. ${ }^{45}$ Currently, this is the only SBP of a TNF inhibitor that has been approved in LA (Table 2). In 2007, Forero ${ }^{87}$ brought to the Colombian Rheumatology Association (CRA) attention some concerns about Etanar. In turn, several members of the CRA conducted an observational study and a pharmacoeconomic study about Etanar. These two studies have been discussed elsewhere. ${ }^{88-90}$ "Etanar Therapy in RealLife Patients with RA" was a multicenter observational study that enrolled 110 patients with active RA who were followed for 20 weeks. ${ }^{89}$ Significant changes in the health assessment questionnaire disability index (HAQ-DI) and the disease activity score (DAS) 28 were observed. HAQ-DI and DAS 28 declined from $2.5 \pm 1.1$ to $1.1 \pm 0.9(P<0.001)$ and from $5.76 \pm 0.81$ to $3.48 \pm 1.12(P<0.001)$, respectively. Side effects were registered in $10 \%$ of the cases. ${ }^{89}$ The authors 
Table 3 Contents of regulations on SBPs in Latin American countries and in other reference documents

\begin{tabular}{lllll}
\hline $\begin{array}{l}\text { Country/territoryl } \\
\text { institution }\end{array}$ & $\begin{array}{l}\text { Regulatory document/ } \\
\text { responsible institution(s) }\end{array}$ & $\begin{array}{l}\text { Year of } \\
\text { publication }\end{array}$ & $\begin{array}{l}\text { Term to designate } \\
\text { SBP }\end{array}$ & Definition of SBP \\
\hline WHO & $\begin{array}{l}\text { Guidelines on Evaluation of Similar } \\
\text { Biotherapeutic Products (SBPS) }\end{array}$ & 2009 & $\begin{array}{l}\text { Similar biotherapeutic } \\
\text { product }\end{array}$ & $\begin{array}{l}\text { A biotherapeutic product that is similar } \\
\text { in terms of quality, safety, and efficacy } \\
\text { to an already-licensed RBP }\end{array}$ \\
European Union & $\begin{array}{l}\text { Guideline on similar biological } \\
\text { medicinal products/EMA }\end{array}$ & 2005 & $\begin{array}{l}\text { Similar biological } \\
\text { medicinal product }\end{array}$ & $\begin{array}{l}\text { A biological medicinal product claiming } \\
\text { to be similar to another already } \\
\text { marketed, in terms of quality, security, } \\
\text { and efficacy }\end{array}$
\end{tabular}

\begin{tabular}{|c|c|c|c|c|}
\hline United States & $\begin{array}{l}\text { Guidance for industry: scientific } \\
\text { considerations in demonstrating } \\
\text { biosimilarity to a reference } \\
\text { product/FDA }\end{array}$ & $\begin{array}{l}\text { Draft } \\
2012\end{array}$ & Biosimilar product & $\begin{array}{l}\text { Biological product that is highly } \\
\text { similar to the reference product, } \\
\text { notwithstanding minor differences } \\
\text { in clinically inactive components. } \\
\text { Additionally, there are no clinically } \\
\text { meaningful differences between the } \\
\text { biological product and the reference } \\
\text { product in terms of safety, purity, } \\
\text { and potency }{ }^{10}\end{array}$ \\
\hline Mexico & $\begin{array}{l}\text { Decree that amends and adds } \\
\text { various provisions to the regulation } \\
\text { of health supplies/President of the } \\
\text { Mexican United States }{ }^{6,11,12}\end{array}$ & 2011 & $\begin{array}{l}\text { Biocomparable } \\
\text { Biotechnological } \\
\text { medicine }\end{array}$ & $\begin{array}{l}\text { Noninnovative biotechnological drug } \\
\text { that proves to be biocomparable } \\
\text { in terms of safety, quality, and } \\
\text { effectiveness, based on the specific tests } \\
\text { established by the law for this purpose }{ }^{12}\end{array}$ \\
\hline Cuba & $\begin{array}{l}\text { Resolution number } 56 / 20 \mathrm{II} \text { : } \\
\text { requisites for the register of } \\
\text { known biological products/Ministry } \\
\text { of Public Health }{ }^{14}\end{array}$ & 2011 & $\begin{array}{l}\text { Known biological } \\
\text { product }\end{array}$ & $\begin{array}{l}\text { A biological product produced by } \\
\text { multiple manufacturers, in which the } \\
\text { active substance is comparable in terms } \\
\text { of quality, safety, and efficacy profiles } \\
\text { to the active substance of an already } \\
\text { licensed RBP in Cuba or in other } \\
\text { countries. The dosage form, strength/ } \\
\text { concentration/potency, and indications } \\
\text { should be the same as those of the RBP }\end{array}$ \\
\hline Guatemala & $\begin{array}{l}\text { Technical standard } 67-2010 \text { : } \\
\text { Sanitary reference registry of } \\
\text { biological and biotechnological } \\
\text { products/Ministry of public } \\
\text { health and social assistance } \\
\text { h5 }\end{array}$ & 2010 & $\begin{array}{l}\text { Biosimilar/ } \\
\text { biocomparable }\end{array}$ & $\begin{array}{l}\text { Is a biologic/biotechnological medication } \\
\text { that has demonstrated by an exercise } \\
\text { of biosimilarity and biocomparability } \\
\text { that is similar or comparable in } \\
\text { terms of quality, safety, efficacy, } \\
\text { and immunogenicity to the reference } \\
\text { medication }{ }^{35}\end{array}$ \\
\hline Costa Rica & $\begin{array}{l}\text { RTCR 440: } 2010 \text {. Regulation on the } \\
\text { inscription and control of biological } \\
\text { medications/Presidency of the } \\
\text { Republic - Ministry of Health }{ }^{42}\end{array}$ & 2010 & Biosimilar medication & $\begin{array}{l}\text { Biological medication that has been } \\
\text { demonstrated by the exercise of } \\
\text { biosimilarity to be similar in terms } \\
\text { of quality, safety, and efficacy to the } \\
\text { reference biological medication }{ }^{42}\end{array}$ \\
\hline Panama & $\begin{array}{l}\text { Executive decree no } 340 \text { : } \\
\text { Sanitary registry of biological } \\
\text { and biotechnological products/ } \\
\text { Presidency of the Republic - } \\
\text { Ministry of Health }{ }^{44}\end{array}$ & 2007 & Not stated & Not defined \\
\hline
\end{tabular}




\section{Requirements for approval of an SBP}

\section{Quality evaluation}

Nonclinical evaluation

Clinical evaluation: ETs are preferred

Pharmacovigilance program ${ }^{4}$

Quality evaluation

Nonclinical evaluation

Clinical evaluation: ETs are requested

Pharmacovigilance program: risk-management program ${ }^{19,64}$

Quality evaluation

Nonclinical evaluation

Clinical evaluation: at least one clinical trial; evaluation

of clinical effectiveness, safety, and immunogenicity

Pharmacovigilance program ${ }^{10}$

Quality evaluation

Nonclinical evaluation: in vitro studies may not be required

if determined by the authorities

Clinical evaluation: will be determined by the quality evaluation

Pharmacovigilance program ${ }^{12}$

Quality evaluation

Nonclinical evaluation

Clinical evaluation

Pharmacovigilance program: postmarketing active surveillance

Quality evaluation

Nonclinical evaluation

Clinical evaluation: PD, PK, efficacy, safety, and immunogenicity

Pharmacovigilance program: risk-management program and

pharmacovigilance plan postregistration ${ }^{35}$

Quality evaluation

Nonclinical evaluation

Clinical evaluation

Pharmacovigilance program: risk-management plan

and postmarketing pharmacovigilance

Quality evaluation

Nonclinical evaluation

Clinical evaluation

Pharmacovigilance program: risk management ${ }^{44}$

\section{Considerations/comments}

Guidance can be adopted as a whole or partially by NRAs or used as a basis for establishing national regulatory frameworks ${ }^{4}$

Applicants should note that the CE for an SBP versus the RBP is an additional element to the normal requirements of the quality dossier. ${ }^{61}$ The clinical evaluation requirements depend on the existing knowledge about the RBP and the claimed therapeutic indication(s). Available product/diseasespecific guidelines should be followed when appropriate. ${ }^{19}$ In certain cases, comparative PK/PD studies between the SBP and the RBP may be sufficient to demonstrate clinical comparability, when some conditions specified in the guideline are met. ${ }^{19}$ Additionally a guideline on nonclinical and clinical issues of mAbs was published in 2012: a step-wise approach where the extent and the nature of the nonclinical and clinical evaluation depend on the level of evidence obtained in the previous step is recommended ${ }^{67}$

A totality-of-the-evidence approach is required for approval of SBPs. ${ }^{10}$ The type and amount of analyses and testing that will be sufficient to demonstrate biosimilarity will be determined on a product-specific basis ${ }^{10}$

Case-by-case basis: the better the quality evaluation and the better comparability is demonstrated, less clinical evidence will be requested for approval of an SBP6,12

The magnitude of the nonclinical and clinical data will depend on the previous knowledge on the RBP, the pharmacologic classification, the specific indication requested, and the differences detected during the quality evaluation. ${ }^{14}$ The clinical trial design can be that of ETs or NITs, or can be PK/PD studies in

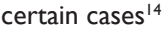

The type and the amount of clinical studies will be determined by the knowledge on the RBP and the therapeutic indications that are being requested. A case-by-case approach will be conducted following the guidelines of the $\mathrm{WHO}$, the ICH, the EMA, and the FDA ${ }^{35}$

The type and the amount of clinical studies will be determined by the knowledge on the RBP and the therapeutic indications that are being requested. A case-by-case approach will be conducted following international guidelines. In the absence of international guidelines, those of the $\mathrm{ICH}$, the EMA, and the FDA could be followed. ${ }^{42}$ In article 6 of this document, five alternatives are stated for selecting the RBP for conducting the $\mathrm{CE}^{42}$

The national direction of pharmacy and medications will use as a reference for the CE the guidelines of the WHO and other guidelines like those of the FDA, $\mathrm{ICH}$, and $\mathrm{EMA}^{44}$ 
Table 3 (Continued)

\begin{tabular}{|c|c|c|c|c|}
\hline $\begin{array}{l}\text { Country/territoryl } \\
\text { institution }\end{array}$ & $\begin{array}{l}\text { Regulatory document/ } \\
\text { responsible institution(s) }\end{array}$ & $\begin{array}{l}\text { Year of } \\
\text { publication }\end{array}$ & $\begin{array}{l}\text { Term to designate } \\
\text { SBP }\end{array}$ & Definition of SBP \\
\hline Colombia & $\begin{array}{l}\text { Draft decree by which decree } 677 \\
\text { of } 1995 \text { is partially modified and the } \\
\text { register of medications of biological } \\
\text { origin for human use is regulated } \\
\text { and other dispositions are dictated/ } \\
\text { Ministry of Health and Social } \\
\text { Protection and the President } \\
\text { of the Republic }\end{array}$ & $\begin{array}{l}\text { Draft } \\
2012^{\mathrm{a}}\end{array}$ & $\begin{array}{l}\text { Medication } \\
\text { of successor } \\
\text { biological origin }\end{array}$ & $\begin{array}{l}\text { Medication whose entry has been later } \\
\text { than a biological medication of first } \\
\text { entry, approved by INVIMA supported } \\
\text { on proper information of quality, } \\
\text { security, and efficacy }{ }^{46}\end{array}$ \\
\hline Venezuela & $\begin{array}{l}\text { Standard for the registry, batch } \\
\text { release and control of biological } \\
\text { products/Ministry of the Popular } \\
\text { Power for Health - National } \\
\text { Institute of Hygiene "Rafael } \\
\text { Rangel"48 }\end{array}$ & 2008 & Not stated & $\begin{array}{l}\text { Not specifically defined. May correspond } \\
\text { to new product } \mathrm{A}_{2} \text { : biologic product, } \\
\text { whose active principle or combination of } \\
\text { active principles are already registered in } \\
\text { the country, but the request of approval } \\
\text { is requested by a producer different } \\
\text { than the pharmaceutical company } \\
\text { of the approved product }{ }^{48}\end{array}$ \\
\hline Peru & $\begin{array}{l}\text { Regulation for the register, } \\
\text { control and vigilance of sanitary } \\
\text { pharmaceutical products, medical } \\
\text { devices, and sanitary products. } \\
\text { Chapter V: biological products/ } \\
\text { constitutional President of the } \\
\text { Republic - Ministry of Economy } \\
\text { and Finance - Ministry of Health }{ }^{51}\end{array}$ & 2011 & $\begin{array}{l}\text { Biosimilar biologic } \\
\text { product }\end{array}$ & Not defined \\
\hline Brazil & $\begin{array}{l}\text { Resolution } 55 \text { of } 2010 \text { : Registration } \\
\text { of new biological products and } \\
\text { biological products and other } \\
\text { dispositions/ANVISA }{ }^{52}\end{array}$ & 2010 & Biological product ${ }^{b}$ & Not specifically defined ${ }^{52}$ \\
\hline Chile & $\begin{array}{l}\text { Proposal of rule on technical } \\
\text { aspects for the evaluation of } \\
\text { biotechnological pharmaceutical } \\
\text { products derived from techniques } \\
\text { of recombinant DNA/Committee of } \\
\text { Biological Products of ANAMED - } \\
\text { Public Health Institute of Chile }\end{array}$ & 2011 & Biosimilar & $\begin{array}{l}\text { Biotechnological drug that has been } \\
\text { demonstrated to be similar in quality, } \\
\text { security, efficacy, and immunogenicity } \\
\text { to the RBP, relying on its comprehensive } \\
\text { characterization, comparative quality } \\
\text { studies, nonclinical and clinical comparative } \\
\text { studies, ie, a comparability study }{ }^{57}\end{array}$ \\
\hline Argentina & $\begin{array}{l}\text { Disposition no } 7075 / \text { Ministry } \\
\text { of Health - Secretary of Politics, } \\
\text { Regulations, and Institutes - } \\
\text { ANMAT }^{59}\end{array}$ & 2011 & Not stated & Not defined \\
\hline
\end{tabular}

Notes: ${ }^{a} \mathrm{~A}$ second version of the draft was published in May 2012 by the Ministry of Health and Social Protection. ${ }^{46}$ bin Brazil, biological product refers to BPs that are not new in Brazil; these include SBPs and other types of copies of the RBP. ${ }^{52}$ This table illustrates the principal characteristics and contents of the pertinent regulatory documents. For more details or for additional consultation, the specific regulation of each country can be consulted.

Abbreviations: SBP, similar biotherapeutic product; BP, biotherapeutic product; RBP, reference biotherapeutic product; WHO, World Health Organization; ETs, equivalence trials; NRAs, national regulatory authorities; EMA, European Medicines Agency; CE, comparability exercise; mAbs, monoclonal antibodies; FDA, Food and Drug Administration; NITs, noninferiority trials; ICH, International Conference on Harmonisation; INVIMA, National Institute of Vigilance of Medications and Food; ANVISA, National Agency of Sanitary Vigilance; ANAMED, National Agency of Medications; ANMAT, National Administration of Food, Medications, and Medical Technology.

concluded that "Etanar can effectively control disease activity in real-life patients with active RA and poor responses to MTX but also other disease-modifying antirheumatic drugs. Safety and tolerability assessment indicates Etanar to be well tolerated." 89

\section{Brazil}

BPs represent $2 \%$ of all the medicines covered and distributed by the Brazilian government; however, this represent $41 \%$ of the total amount that the Ministry of Health spends annually on medicines through specific health programs; mAbs 


\section{Requirements for approval of an SBP}

\section{Essential information}

Quality evaluation

Immunogenicity testing: according to the guidelines

established by the Ministry of Health and Social Protection

Pharmacovigilance program: risk-management plan

Quality evaluation

Nonclinical evaluation

Clinical evaluation

Pharmacovigilance program: active pharmacovigilance

plan during the first year ${ }^{42}$

Quality evaluation

Nonclinical evaluation: in vitro studies will not be required

if determined by the pertinent authorities

Clinical evaluation

Pharmacovigilance program: risk-management plan $^{51}$

Quality evaluation

Nonclinical evaluation

Clinical evaluation

Pharmacovigilance program

The amount of requested studies in each level depends on the pathway (comparability or individual). ${ }^{71}$ More emphasis is given to clinical studies. Nonclinical studies are not dispensable ${ }^{7 /}$ Quality evaluation

Nonclinical evaluation: at least one study in vitro and one repeated-dose toxicity study in an animal model

Clinical evaluation: including clinical studies of immunogenicity unless these data can be generated by clinical studies that evaluate safety Pharmacovigilance program: risk-management plan $^{57}$

Quality evaluation

Nonclinical evaluation

Clinical evaluation

Pharmacovigilance program: integral system of report,

epidemiological analysis, and risk management ${ }^{59}$

\section{Considerations/comments}

The review commission of the chamber of drugs and biologicals of INVIMA will establish conclusive evidence of the safety and the efficacy of the SBP based on the essential information provided by the manufacturer of the SBP. If this evidence is not conclusive, complementary information will be required: comparability exercise, nonclinical evaluation, and clinical trials. ${ }^{46}$ The specific designs or studies within the clinical evaluation are not established ${ }^{46}$

BPs are classified in different categories. The requisites for the approval will depend on the specific category. Every biological product will be considered as a new one for obtaining its sanitary registry ${ }^{48}$

Preclinical and clinical studies must demonstrate comparability between the RBP and the SBP. The degree of similarity in the quality evaluation will determine the extension of the nonclinical and clinical studies ${ }^{51}$ The comparability exercise will be based on the guideline of the $\mathrm{WHO}^{4,51}$

BPs can be licensed by a comparative pathway or by an individual development pathway. ${ }^{52,71}$ In the individual pathway, a reduced dossier can be presented; however, at least one comparative NIT with the RBP must be presented. Within this pathway, indications cannot be extrapolated to those of the RBP. ${ }^{71}$ Only the copies licensed by the comparability pathway are considered as SBPs and could claim for extrapolation of indications. ${ }^{71}$ Brazilian regulation regarding license of SBPs is not related to patent issues ${ }^{71}$ For specific class products like mAbs, the specific guidelines developed for this purpose by the EMA must be followed. ${ }^{57}$ Preclinical and clinical studies will be requested on a case-by-case basis according to the comparability in the quality evaluation; for nonclinical studies, at least one study in vitro and one animal model. ${ }^{57}$ For clinical studies, comparative immunogenicity and extension studies must be developed. At least one comparative PK/PD study must be conducted ${ }^{57}$

Within the clinical evaluation, phase I, II, and III studies must be included ${ }^{59}$ account for the $32 \%$ of the total amount spent on BPs by the Brazilian Ministry of Health. ${ }^{71}$ In 2002, the first regulation related to BPs was published; the same pathway was contemplated for RBPs and for SBPs. ${ }^{71}$ At the end of 2010, given the national and international interest and questions on SBPs, the
National Health Surveillance Agency (ANVISA) published the current guidelines (Table 3). ${ }^{52,71}$ This guideline established two pathways for the approval of SBPs: comparative and individual. ${ }^{52}$ Special importance is given to the clinical evaluation within both pathways; the nonclinical evaluation 
is not dispensable. ${ }^{71,91}$ The Brazilian guidelines follow the same scientific principles as the WHO guidelines, but also have some differences, which are due to specific country needs. ${ }^{71}$ Since 2005, the NRAs of Brazil (ANVISA) and Cuba (CECMED), through an agreement between both countries, created the Technical Regulatory Committee (TRC) to follow all the activities related to technology-transfer projects. ${ }^{71}$ This TRC has members from different areas of the Brazilian and Cuban NRAs, as well as members from different areas of the Cuban and Brazilian producers. ${ }^{71}$ A project for the development of an interferon alpha-2b has already been developed by the TRC. ${ }^{71}$ In 2010, Azevedo highlighted the importance of the formulation process of SBPs, which goes from the type of administration to the final use by the patient. ${ }^{92} \mathrm{He}$ argued that the possible differences in this aspect between the RBP and the SBP must be clearly and publicly stated by both manufacturers, that safe application of BPs depends on informed and appropriate use by health-care professionals, and that the role of prescribing physicians is of great importance, given that the exchange between RBPs and SBPs is their responsibility, as well as the obligation of promptly communicating loss of efficacy and signs that indicate differences in immunogenicity between the RBP and the SBP. ${ }^{92}$ In 2011, Azevedo et al studied the opinion of some Brazilian rheumatologists about SBPs. ${ }^{93}$ One-third of the professionals reported not being familiar with what SBPs were and what seemed reasonable, since the subject was relatively new to rheumatologists. ${ }^{93}$ Most interviewees indicated low price as an undeniable advantage of SBPs. Regarding the approval of SBPs, few professionals considered it important that an SBP had different nomenclature from the RBP. ${ }^{93}$ Of note, this research evidenced the lack of information on the matter, and claimed for academic and unbiased discussions about differences between RBPs and SBPs among physicians, especially rheumatologists. ${ }^{93}$

The Brazilian government is supporting two companies, Bionovis and Orygen, wishing to be the first national companies to develop SBPs. On the other hand, Sandoz, which is based in Cambé, Paraná, already markets Omnitrope, the first $\mathrm{SBP} / \mathrm{rhGH}$ follow-on protein, and also is conducting clinical trials on other SBPs, including RTX.

\section{Chile}

Currently, there are guidelines on the approval of SBPs that follow the accepted international standards (Table 3). In 2006, Saavedra and Quiñones ${ }^{94}$ described considerations pertaining to the interchangeability of BPs and the approval of SBPs in Chile. The authors stated that the Public Health
Institute and the Ministry of Health of Chile must consider that for BPs there are no interchangeable generics, and must also consider that the bioequivalence of these medications should be addressed on a case-by-case basis following nonclinical and clinical studies that can demonstrate efficacy and safety. ${ }^{94}$ In 2010, the Chilean Society of Rheumatology issued a statement on the authorization of SBPs, supporting their development based on the patient's right to have better access to appropriate and timely treatment. ${ }^{95}$ The concerns of these two articles mentioned ${ }^{94,95}$ were solved by the current Chilean guidelines on SBPs. ${ }^{57}$

\section{Argentina}

In November 2011, the regulation on SBPs was enacted. The document was based on international standards (Table 3). ${ }^{59} \mathrm{In}$ this country, no SBPs have been licensed for utilization in RA or other ADs. ${ }^{58}$ In 2009, Matar ${ }^{96}$ highlighted the importance of following updated and specific legislation for the approval of SBPs and also emphasized the importance of conducting clinical trials designed for testing the efficacy and security of SBPs before their approval. ${ }^{96}$ This point of view was published before the enactment of the current regulation.

\section{Discussion}

The regulation and marketing of competing SBPs has aroused much controversy worldwide, especially regarding the number and the stringency of the requirements for their approval. This aspect is complex given the different interests involved: transnational pharmaceutical companies producers of RBPs, pharmaceutical companies producers of SBPs, local markets and importers of SBPs, governments and health authorities, patients and health professionals, as well as scientific societies. The debate regarding the regulation of SBPs should consider effectiveness, safety, cost containment, and reasonable profits. On one side, the effectiveness and safety of the new molecules and SBPs must be guaranteed, and on the other side access to these medicines must be sought. Cost containment is also critical given that the sustainability of modern health systems in a scenario of advanced medicine and expensive interventions is a great challenge. ${ }^{97}$ Satisfying patent exclusivity and reasonable profits of the manufacturers of RBPs has to be weighed against the sustainability of the health systems and the entry to market of SBPs, also in the context of reasonable profits for manufacturers of SBPs. Some authors believe that the current controversy is artificial and promoted, probably by the pharmaceutical companies that produce the RBPs, who perceive the entry of SBPs as a menace to their profits and monopoly. ${ }^{8}$ These authors argue 
that it should not be controversial, because the entry of SBPs is beneficial as long as these products can achieve the requisites of quality and comparability that have been defined by serious regulatory institutions like the EMA. ${ }^{8}$

The debate can be more difficult when the context is that of low- and middle-income countries, like most of the nations of LA. In this case, the necessity of adequate access to BPs is high, and the opportunity for the community and for patients of low resources to obtain expensive treatment for ADs and other chronic diseases is low. Then, some questions appear. How much stringency in the evaluation of SBPs are LA countries willing to sacrifice for cost containment and sustainability of health systems? How much uncertainty on effectiveness and security of SBPs are health authorities in LA willing to sacrifice for better access to high-cost medications such as BPs? Some LA countries like Mexico, Peru, Ecuador, Chile, Bolivia, and Colombia are already marketing SBPs of biological therapies used for autoimmune rheumatic diseases (Table 2). In Colombia and Chile, these SBPs were approved before the publishing of current regulations or drafts. ${ }^{45,72}$ In China and India, some SBPs for RA have also been approved. ${ }^{9}$

Some LA countries have shown important growth in their biotechnology industries: Mexico, through the local manufacturer Probiomed, developed an SBP of RTX that is already being marketed in the country, contributing to the growth of the Mexican biotechnology industry. ${ }^{78} \mathrm{Cuba}$ has a structured national industry that produces around half of the BPs that are approved and marketed in the country, specifically vaccines, and it also exports some of these BPs. ${ }^{13}$ In Brazil, there are some national producers of BPs with broad experience in the production of vaccines, and that recently have begun to produce other BPs like erythropoietin and interferon. ${ }^{71}$ In this country, the interest and investment of private and public national producers in the biological market has increased in an important way in the last few years. ${ }^{71} \mathrm{An}$ agreement was reached in 2005 between Cuba and Brazil for the development and follow-up of BPs. ${ }^{71}$ These cases are examples of the important role that biotechnology can have on national scientific and economic growth in Latin American countries.

In the case of Colombia, the average cost per patient per year of therapy with TNF inhibitors was estimated for 2009 as US\$23,464 from the payer's perspective, ${ }^{98}$ which is more than four times the Colombian gross domestic product per capita for that period. ${ }^{99}$ Colombian health funds have been seriously affected by BPs and high-cost medicines. In the last 3 years, eight of the ten principal medications reimbursed by
Fund of Solidarity and Guarantees (FOSYGA) corresponded to BPs; between 2008 and 2011, around \$334,728,000 was paid by FOSYGA for reimbursements of 15 BPs. ${ }^{100}$ Part of this phenomenon has been blamed on the multinational pharmaceutical industry through attempting to impose rules that prevent entry of drugs that can compete with those already being sold in the country. ${ }^{100}$ It is noteworthy that BPs in Colombia are much more expensive than in other countries. ${ }^{85,101}$ For example, RTX and infliximab have been estimated to be much more expensive in Colombia than in the United Kingdom: $1.217 \%$ and $94.2 \%$, respectively. ${ }^{101}$ Another concern that has been stated by the Colombian media is the possible negative effects that the free-trade agreement with the US may have on the national market of biotechnology and on access to BPs and SBPs ${ }^{102}$ because of the specifications on patents and intellectual property established in the free-trade agreement. ${ }^{102,103}$

The entry of SBPs is a phenomenon prone to controversy, given the different affected parties. In Colombia, the approval of Etanar raised different opinions among health professionals, as was discussed previously. ${ }^{87,89,90}$ In Mexico, a similar controversy was seen when Kikuzubam was approved, which involved the local manufacturer, the manufacturer of the innovator RBP, the government, and other parties. ${ }^{77,79}$ Yet in a panorama like the present Colombian scenario, where the prices of BPs are exorbitant, the funding of the health system is affected by reimbursements of BPs, and where access to these medicines is restricted, it is undoubtedly the case that the entry of SBPs will be beneficial. Nevertheless, this entry of SBPs must be framed within a clear and consistent regulation that ensures quality, effectiveness, and safety.

\section{Conclusion}

The advent of SBPs is definitely beneficial, because it promotes cost containment favoring the sustainability of modern health systems in a panorama of aging population, demographic transition towards chronic diseases like ADs, costly health technologies, and limited resources. Additionally, SBPs promote better access to BPs, benefiting affected individuals and promoting competition within the market of biotechnology, favoring some parties of local Latin American markets and economies, as in the case of Mexico, Brazil, and Cuba. The advent of these medications gains more importance in Latin American countries, given that most of these nations are low- and middle-income countries.

Nowadays, the trend in LA is toward the adoption of accepted international standards, like those presented by the WHO. ${ }^{104}$ This tendency has been seen in regional experiences 
like those of Guatemala, Panama, Costa Rica, Peru, Chile, Brazil, and Argentina, where recent guidelines have been developed based on and/or contemplating internationally accepted standards. For the rest of LA countries where specific regulations on SBPs have not been developed, efforts must be conducted for the construction of updated and consistent guidelines in the short term, given the necessity for clear legislation on this matter.

Case-by-case bases, if performed in a transparent way and guided by scientific and objective standards, can allow simplification of the approval of SBPs in specific cases, which favors the efficiency of the approval process by reducing the extent of the requisites. Losing certainty on efficacy and safety by improving patient access with exceptionally abbreviated approval processes is a risk that can be assumed by some governments, but that would be outside the accepted current recommendations on the approval of SBPs. The future perspectives in Europe, US, LA, and other regions are toward the accelerated growth of the industry of biotechnology and toward the increasing entry of SBPs for use in ADs, given the expiry of the patents of RBP and the advent of rising investment in the industry and the manufacturing of SBPs. These factors are expected to be beneficial, because they can promote innovation, competition, access, and efficiency at affordable prices.

\section{Acknowledgment}

The authors express their gratitude to our colleges at the CREA for their fruitful opinions and contributions.

\section{Disclosure}

The authors report no conflicts of interest in this work.

\section{References}

1. Sekhon BS, Saluja V. Biosimilars: an overview. Biosimilars. 2011;1: $1-11$.

2. Dranitsaris G, Amir E, Dorward K. Biosimilars of biological drug therapies: regulatory, clinical and commercial considerations. Drugs. 2011;71:1527-1536.

3. Kay J. Biosimilars: a regulatory perspective from America. Arthritis Res Ther. 2011;13:112.

4. World Health Organization. Guidelines on Evaluation of Similar Biotherapeutic Products (SBPS). Geneva: WHO; 2009. Available from: http://www.who.int/biologicals/publications/trs/areas/biological_ therapeutics/BS2110Dft_guidelines_Final_HK_IK_29 July_09.pdf. Accessed June 1, 2012.

5. Roger SD. Biosimilars: current status and future directions. Expert Opin Biol Ther. 2010;10:1011-1018.

6. Silva CL. México retoma un liderazgo regulatorio sobre medicamentos biotecnológicos y biocomparables. Gac Med Mex. 2012;148:83-90.

7. Asociación de Industrias Farmacéuticas Colombianas. Propuesta de Decreto para la Aprobación de Medicamentos Biotecnológicos en Colombia. Bogotá: ASINFAR, Generación BIO; 2011. Available from: http://asinfar.com/Archivos/PROPUESTA_DE_REGULACION_ BIOTECNOLOGICOS.pdf. Accessed June 4, 2012.
8. Dorantes Calderon B, Montes Escalante IM. Medicamentos Biosimilares. Controversias científicas y legales. Farm Hosp. 2010;34:29-44.

9. Scheinberg MA, Kay J. The advent of biosimilar therapies in rheumatology - "O brave new world." Nat Rev Rheumatol. 2012;7:430-436.

10. Food and Drug Administration. Guidance for industry: scientific considerations in demonstrating biosimilarity to a reference product. 2012. Available from: http://www.fda.gov/downloads/Drugs/GuidanceComplianceRegulatoryInformation/Guidances/UCM291128.pdf. Accessed July 5, 2012.

11. Boardman ES. Mexico at the vanguard: a new era in medicines of biotechnological origin. J Generic Med. 2010;7:4-7.

12. Presidente de los Estados Unidos Mexicanos. Reglamento de Insumos para la Salud. 2011. Available from: http://www.cofepris.gob.mx/MJ/ Documents/Reglamentos/rtoinsumos.pdf. Accessed July 5, 2012.

13. Hechavarría Núñez Y, Pérez Massipe RO, Orta Hernández SD, et al. The regulatory framework for similar biotherapeutic products in Cuba. Biologicals. 2011;39:317-320.

14. Ministerio de Salud Pública, República de Cuba. Requisitos para el Registro de Productos Biológicos Conocidos. Havana: Ministerio de Salud Pública; 2011. Available from: http://www.cecmed.sld.cu/Docs/ Pubs/AmbReg/2011/AmbReg-126.pdf. Accessed July 10, 2012.

15. Genazzani AA, Biggio G, Caputi AP, et al. Biosimilar drugs: concerns and opportunities, BioDrugs. 2007;21:351-356.

16. European Medicines Agency. Guideline on similar biological medicinal products. 2005. Available from: http://www.ema.europa.eu/docs/en_ GB/document_library/Scientific_guideline/2009/09/WC500003517. pdf. Accessed July 7, 2012.

17. Zuniga L, Calvo B. Biosimilars approval process. Regul Toxicol Pharmacol. 2010;56:374-377.

18. McCamish M, Woollett G. Worldwide experience with biosimilar development. MAbs. 2011;3:209-217.

19. European Medicines Agency. Guideline on similar biological medicinal products containing biotechnology derived-proteins as active substance: non-clinical and clinical issues. 2006. http://www.ema. europa.eu/docs/en_GB/document_library/Scientific_guideline/2009/09/ WC500003920.pdf. Accessed July 5, 2012.

20. Simoens S. Biosimilar medicines and cost-effectiveness. Clinicoecon Outcomes Res. 2011;3:29-36.

21. Smolen JS, Landewe R, Breedveld FC, et al. EULAR recommendations for the management of rheumatoid arthritis with synthetic and biological disease-modifying antirheumatic drugs. Ann Rheum Dis. 2010;69:964-975.

22. Augustsson J, Neovius M, Cullinane-Carli C, Eksborg S, van Vollenhoven RF. Patients with rheumatoid arthritis treated with tumour necrosis factor antagonists increase their participation in the workforce: potential for significant long-term indirect cost gains (data from a population-based registry). Ann Rheum Dis. 2010;69:126-131.

23. Benucci M, Li Gobbi F, Sabadini L, Saviola G, Baiardi P, Manfredi M. The economic burden of biological therapy in rheumatoid arthritis in clinical practice: cost-effectiveness analysis of sub-cutaneous antiTNFalpha treatment in Italian patients. Int J Immunopathol Pharmacol. 2009,22:1147-1152.

24. Wu E, Chen L, Birnbaum H, Yang E, Cifaldi M. Cost of care for patients with rheumatoid arthritis receiving TNF-antagonist therapy using claims data. Curr Med Res Opin. 2007;23:1749-1759.

25. European Medicines Agency. Biosimilar medicines authorised by the EMA. http://www.ema.europa.eu/ema/index.jsp?curl=pages\%2Fme dicines $\% 2$ Flanding\%2Fepar_search.jsp\&murl=menus $\% 2$ Fmedicines $\% 2$ Fmedicines.jsp\&mid=WC0b01ac058001d124\&searchTab=search ByAuthType \&alreadyLoaded=true \&isNewQuery=true\&status=Auth orised \&status $=$ Withdrawn $\&$ status $=$ Suspended $\&$ status $=$ Refused $\&$ key word=Enter+keywords \&searchType=name $\&$ taxonomyPath $=\&$ treeN umber $=\&$ searchGeneric Type $=$ biosimilars $\&$ genericsKeywordSearch $=$ Submit. Accessed July 5, 2012.

26. Food and Drug Administration. National drug code query - active ingredient. Available from: http://www.accessdata.fda.gov/scripts/cder/ ndc/activeingredient.cfm. Accessed July 5, 2012. 
27. Comisión Federal para la Protección contra Riesgos Sanitarios. Registros sanitarios de medicamentos. 2012. Available from: http://www.cofepris.gob.mx/AS/Paginas/Registros\%20Sanitarios/ RegistroSanitarioMedicamentos.aspx. Accessed July 2, 2012.

28. Centro para el Control Estatal de Medicamentos. Medicamentos y biológicos - aprobados. 2012. Available from: http://www.cecmed. sld.cu/Docs/RegSan/RegSanMed.xls. Accessed June 24, 2012.

29. Dirección General de Drogas y Farmacias. Consulta medicamentos. 2012. Available from: http://drogasyfarmacias.gov.do/index.php?option=com wrapper\&view=wrapper\&Itemid=437. Accessed July 5, 2012.

30. Dirección General de Drogas y Farmacias. Requisitos medicamentos. 2012. Available from: http://www.drogasyfarmacias.gov.do/index.php. Accessed July 5, 2012.

31. Departamento de Salud Gobierno de Puerto Rico. [Homepage on the Internet.] Available from: http://www.salud.gov.pr. Accessed July 5, 2012.

32. Departamento de Salud Gobierno de Puerto Rico. Reglamentos. 2007. Available from: http://www.salud.gov.pr/Publicaciones/Reglamentos/ Pages/default.aspx. Accessed July 5, 2012.

33. Ministère de la Santé et de la Population. Recherche. Available from http://www.mspp.gouv.ht/site/index.php?searchword=enbrel\&orderi $\mathrm{ng}=$ newest\&searchphrase=all\&option=com_search. Accessed July 5, 2012.

34. Ministerio de Salud Pública y Asistencia Social. Registros sanitarios de medicamentos vigentes. 2012. Available from: http://www.mspas. gob.gt/index.php?option=com_wrapper\&view=wrapper\&Itemid $=186$ Accessed July 5, 2012.

35. Ministerio de Salud Pública y Asistencia Social. Norma técnica 67-2010 Registro sanitario de referencia de productos biológicos y biotecnológicos. 2010. Available from: http://www.mspas.gob.gt/images/stories/ informacion_servicios/productos_farmaceuticos/normativas/nt_672010.pdf. Accessed July 5, 2012.

36. Secretaria de Salud, Gobierno de Unidad Nacional, Honduras. Tegucigalpa. Available from: http://www.salud.gob.hn/\#. Accessed July 5, 2012.

37. Ministerio de Salud. Listado Oficial de Medicamentos. 10a versión. San Salvador: Ministerio de Salud Publica y Asistencia Social Dirección de Regulación Unidad Reguladora de Medicamentos e Insumos Médicos; 2012. Available from: http://asp.mspas.gob.sv/regulacion/pdf/ listados/Listado_oficial_de_medicamentos_10a.pdf. Accessed July 5, 2012.

38. Ministerio de Salud. Inclusiones al Listado Oficial de Medicamentos. 10a versión. 2011. Available from: http://asp.mspas.gob.sv/regulacion/ pdf/listados/Listado_Oficial_de_medicamentos_10a_version_ Adendas_2011_2.pdf. Accessed July 5, 2012.

39. Ministerio de Salud. Dirección de medicamentos y productos sanitarios. 2012. Available from: http://www.salud.gob.sv/index.php/temas/ politicas-de-salud/dir-med-prod-sanitarios. Accessed July 5, 2012.

40. Ministerio de Salud. Dirección de farmacia. 2011. Available from: http:// www.minsa.gob.ni/index.php?option=com_remository\&Itemid $=52 \& \mathrm{f}$ unc $=$ select\&id=1842. Accessed July 9, 2012.

41. Ministerio de Salud. Productos registrados. 2012. Available from: http:// www.ministeriodesalud.go.cr/index.php/empresas-servicios-productosregistrados-ms. Accessed July 10, 2012.

42. Presidencia de la República y la Ministra de Salud. RTCR 440: 2010. Reglamento de inscripción y control de medicamentos biológicos. 2012. Available from: http://www.pgr.go.cr/Scij/ Busqueda/Normativa/Normas/nrm_repartidor.asp?param1=NRTC\&n Valor $1=1 \&$ nValor $2=72232 \&$ nValor $3=88031 \&$ strTipM=TC. Accessed July 10, 2012.

43. Ministerio de Salud, República de Panamá. [Homepage on the Internet.] Available from: http://www.minsa.gob.pa. Accessed July 11, 2012.

44. República de Panamá Ministerio de Salud. Decreto ejecutivo no 340. 2007. Available from: http://www.minsa.gob.pa/minsa/tl_files/documents/informacion_salud/farmacias_drogas/registro_sanitario/ marco_legal/reg_sanitario/Decreto $\% 20340 \% 20$ (modifica $\% 20$ el $\% 20$ 178\%20sobre\%20biotecnologicos).pdf. Accessed July 11, 2012.
45. Instituto Nacional de Vigilancia de Medicamentos y Alimentos. Etanar. Available from: http://web.sivicos.gov.co:8080/consultas/consultas/ consreg_encabcum.jsp. Accessed June 27, 2012.

46. Ministerio de Salud y Protección Social, Presidente de la República de Colombia. Segunda propuesta decreto para la reglamentación de productos biotecnológicos en Colombia. 2012. Available from: http://www.minsalud.gov.co/Politicas\%20Farmaceuticas/ Biotecnol\%C3\%B3gicos/23052012_Segunda\%20versi\%C3\%B3n_ Biotecnologicos.pdf. Accessed June 25, 2012.

47. Ministerio del Poder Popular para la Salud, Instituto Nacional de Higiene "Rafael Rangel." Productos biológicos aprobados en Venezuela. 2012. Available from: http://190.202.114.146:7474/pb/aprobados_pb/ aprobados.html. Accessed July 2, 2012.

48. Instituto Nacional de Higiene "Rafael Rangel." Norma para el registro, liberación de lotes y control de los productos biológicos. 2008. Available from: http://www.inhrr.gob.ve/pb/pdf/Norma_PB.pdf. Accessed July 11, 2012.

49. Ministerio de Salud Pública del Ecuador. [Homepage on the Internet.] Available from: http://www.salud.gob.ec/. Accessed July 12, 2012.

50. Ministerio de Salud. Reditux $100 \mathrm{mg} / 10 \mathrm{~mL}$ : registro de productos farmacéuticos (ex-perudis). 2012. Available from: http://www. datosperu.org/registro-marcas-reditux-404514.php. Accessed July 12, 2012.

51. Presidente Constitucional de la república, Ministerio de Salud. Reglamento para el registro, control y vigilancia sanitaria de productos farmacéuticos, dispositivos médicos y productos sanitarios. Capítulo $\mathrm{V}$ : de los productos biológicos. 2011. Available from: http://observatorio digemid.minsa.gob.pe/OPMSCMS/Archivos/DS016-2011-MINSA. pdf. Accessed July 12, 2012.

52. Agência Nacional de Vigilância Sanitária. Resolução RDC n 55 de 16 de Dezembro de 2010: Dispõe sobre o registro de produtos biológicos novos e produtos biológicos e dá outras providências. 2010. Available from: http://www.desenvolvimento.gov.br/portalmdic/arquivos/ dwnl_1307385325.pdf. Accessed July 12, 2012.

53. Ministerio de Salud y Deportes. Registro sanitario de medicamentos nacionales e importados. 2012. Available from: http://www.sns.gob. bo/aplicacionesweb/unimed/unimed/consultas-reg-san.htm\#. Accessed July 12, 2012.

54. Ministerio de Salud y Deportes. Normativas. 2012. Available from: http://www.sns.gob.bo/index.php?ID=Normativas. Accessed July 12, 2012.

55. Ministerio de Salud Pública y Bienestar Social. [Homepage on the Internet.] Available from: http://www.mspbs.gov.py/v2/index.php. Accessed July 12, 2012.

56. Ministerio de Salud Pública. [Homepage on the Internet.] Available from: http://www.msp.gub.uy/index_1.html. Accessed July 12, 2012.

57. Ministerio de Salud. Propuesta de norma y aspectos técnicos para la evaluación de productos farmacéuticos biotecnológicos derivados de técnicas ADN recombinantes. Santiago: Instituto de Salud Pública de Chile; 2011. Available from: http://www.ispch.cl/sites/default/ files/documento/2011/11/Pro_Norma_Biotecnologicos.pdf. Accessed July 12, 2012.

58. Ministerio de Salud. Vademécum farmacológico de la ANMAT. Available from: http://www.anmat.gov.ar/aplicaciones_net/applications/consultas/vademecum/vademecum.asp. Accessed July 12, 2012.

59. Ministerio de Salud. Disposición 7075. Administración Nacional de Medicamentos Alimentos y Tecnología Médica. 2011. Available from: http://www.anmat.gov.ar/boletin_anmat/octubre_2011/Dispo_7075-11. pdf. Accessed July 12, 2012.

60. Agência Nacional de Vigilância Sanitária. Consulta a bancos de dados: medicamentos. Available from: http://www.anvisa.gov.br/scriptsweb/ Medicamento.HTM. Accessed July 2, 2012.

61. European Medicines Agency. Guideline on similar biological medicinal products. Available from: http://www.ema.europa.eu/docs/en_GB/ document_library/Scientific_guideline/2009/09/WC500003517.pdf. Accessed July 2, 2012. 
62. European Medicines Agency. Guideline on immunogenicity assessment of biotechnology-derived therapeutic proteins. Available from: http:// www.ema.europa.eu/docs/en_GB/document_library/Scientific_ guideline/2009/09/WC500003946.pdf. Accessed July 5, 2012.

63. European Medicines Agency. Multidisciplinary: biosimilar. Available from: http://www.ema.europa.eu/ema/index.jsp?curl=pages/regulation/ general/general_content_000408.jsp\&mid=WC0b01ac058002958c. Accessed July 30, 2012.

64. European Medicines Agency. Concept paper on the revision of the guideline on similar biological medicinal products containing biotechnology-derived proteins as active substance: non-clinical and clinical issues. 2011. Available from: http://www.ema.europa. eu/docs/en_GB/document_library/Scientific_guideline/2011/10/ WC500115611.pdf. Accessed July 5, 2012.

65. European Medicines Agency. Concept paper on the revision of the guideline on similar biological medicinal product. 2011. Available from: http://www.ema.europa.eu/docs/en_GB/document_library/ Scientific_guideline/2011/11/WC500117987.pdf. Accessed July 5, 2012.

66. European Medicines Agency. Guideline on similar biological medicinal products containing biotechnology-derived proteins as active substance: quality issues - (revision 1). 2012. Available from: http://www.ema. europa.eu/docs/en_GB/document_library/Scientific_guideline/2012/05/ WC500127960.pdf. Accessed July 5, 2012.

67. European Medicines Agency. Guideline on similar biological medicinal products containing monoclonal antibodies - non-clinical and clinical issues. 2012. Available from: http://www.ema.europa.eu/docs/en_GB/ document_library/Scientific_guideline/2012/06/WC500128686.pdf. Accessed July 5, 2012.

68. Food and Drug Administration. Biologics Price Competition and Innovation Act of 2009. 2012. Available from: http://www.fda.gov/ downloads/Drugs/GuidanceComplianceRegulatoryInformation/ UCM216146.pdf. Accessed July 5, 2012.

69. Food and Drug Administration. Guidance for industry: quality considerations in demonstrating biosimilarity to a reference protein product. 2012. Available from: http://www.fda.gov/downloads/Drugs/ GuidanceComplianceRegulatoryInformation/Guidances/UCM291134. pdf. Accessed July 5, 2012.

70. Knezevic I, Griffiths E. Biosimilars. Global issues - national solutions. Biologicals. 2011;39:252-255.

71. Castanheira LG, Barbano DB, Rech N. Current development in regulation of similar biotherapeutic products in Brazil. Biologicals. 2011;39:308-311.

72. Ministerio de Salud. Sistema de Consulta de Productos Registrados: Reditux concentrado para solución para infusión $10 \mathrm{mg} / \mathrm{mL}$. 2010. Available from: http://200.68.11.21/RegistrosISP/fiFichaProducto. asp?RegistroISP=B-2142/10. Accessed July 2, 2012.

73. Pombo ML. Biotechnological products in Pan American Health Organization (PAHO): regional efforts towards harmonization of regulation. Biologicals. 2011;39:348.

74. Pombo ML, Di Fabio JL, Cortés MDIA. Review of regulation of biological and biotechnological products in Latin American and Caribbean countries. Biologicals. 2009;37:271-276.

75. Presidente de los Estados Unidos Mexicanos. Decreto por el que se adiciona un artículo 222 Bis a la Ley General de Salud. 2009. Available from: http://dof.gob.mx/nota_detalle.php?codigo $=5094117 \&$ fecha=11/ 06/2009. Accessed July 2, 2012.

76. Comisión Federal para la Protección contra Riesgos Sanitarios. Diario oficial publica lineamientos para medicamentos biotecnológicos biocomparables. 2012. Available from: http://www.google.com.co/ url? $\mathrm{sa}=\mathrm{t} \& \mathrm{rct}=\mathrm{j} \& \mathrm{q}=$ Diario + oficial + publica + lineamientos + para $+\mathrm{me}$ dicamentos+biotecnol $\% \mathrm{C} 3 \% \mathrm{~B} 3$ gicos + biocomparables\&source $=$ we $\mathrm{b} \& \mathrm{~cd}=1 \& \mathrm{ved}=0 \mathrm{CC} 4 \mathrm{QFjAA} \& u r \mathrm{l}=\mathrm{http} \% 3 \mathrm{~A} \% 2 \mathrm{~F} \% 2 \mathrm{Fwww}$. cofepris. gob.mx\%2FDocuments\%2FNotasPrincipales\%2Fbiotecnologicos.p df\&ei=FmLJUKixPISO8wSKp4HwBQ\&usg=AFQjCNHMD3s5H0 UMe_DuNIs3U4jHI5gkoQ\&bvm=bv.1355272958,d.eWU. Accessed July 2, 2012.
77. Coronel MR. Los biocomparables del futuro y el papel de Probiomed. El Economista. 2012. Available from: http://eleconomista.com.mx/ columnas/columna-especial-empresas/2012/03/25/biocomparablesfuturo-papel-probiomed. Accessed July 5, 2012.

78. Kikuzubam, Probiomed. 2012. Available from: http://www. probiomed.com.mx/themes/probiomed/alta_especialidad. html keepThis $=$ true $\&$ TB_iframe $=$ true $\&$ height $=340 \&$ width $=600$. Accessed June 24, 2012.

79. Coronel MR. Se enfrentan Roche y Probiomed. El Economista. 2010. Available from: http://eleconomista.com.mx/industrias/2010/11/25/ se-enfrentan-roche-probiomed. Accessed July 5, 2012.

80. Probiomed. [Homepage on the Internet.] Available from: http://www. probiomed.com.mx. Accessed June 24, 2012.

81. Ministerio de Salud y Protección Social, Presidencia de la República de Colombia. Propuesta decreto para la reglamentación de productos biotecnológicos en Colombia. 2012. Available from: http://www. minsalud.gov.co/Normatividad/Proyecto\%20Decreto\%20Biológico $\% 20$ -Biotecnológicos.pdf. Accessed June 12, 2012.

82. Ministerio de Salud y Protección Social. Se abre la segunda ronda de discusión del decreto sobre biológicos y biotecnológicos. 2012. Available from: http://www.minsalud.gov.co/Paginas/Se $\% 20$ abre $\% 201 \mathrm{a} \% 20$ segunda $\% 20$ ronda $\% 20 \mathrm{de} \% 20$ discusi $\% \mathrm{C} 3 \% \mathrm{~B} 3 \mathrm{n} \% 20$ de $1 \% 20$ decreto $\% 20$ sobre $\% 20$ biol $\%$ C $3 \%$ B 3 gicos $\% 20$ y $\% 20$ biotecnol\%C3\%B3gicos.aspx. Accessed June 27, 2012.

83. Correa J. Puja por biotecnológicos pone en juego $\$ 1.4$ billones. Portafolio. 2012. Available from: http://www.portafolio.co/economia/pujabiotecnologicos-pone-juego-14-billones. Accessed June 21, 2012.

84. [No author listed.] Afirmaciones de Afidro son temerarias: Minsalud. Portafolio. 2012. Available from: http://www.portafolio.co/economia/ minsalud-rechaza-afirmaciones-afidro-biotecnologico. Accessed July 6 , 2012.

85. Sardi E. Bioterrorismo. Portafolio. 2012. Available from: http://www. portafolio.co/columnistas/bioterrorismo. Accessed July 6, 2012.

86. Correa P. La guerra por los medicamentos biotecnológicos en Colombia. El Espectador. 2012. Available from: http://m.elespectador.com/ impreso/temadeldia/articulo-326234-estimado-philippe-convenido. Accessed July 5, 2012.

87. Forero E. Terapia biológica - su realidad científica y social. Rev Col Reumatol. 2007;14:7-8

88. Geiler J, Buch M, McDermott MF. Anti-TNF treatment in rheumatoid arthritis. Curr Pharm Des. 2011;17:3141-154.

89. Rondon F, Bautista A, Salazar JC, et al. Etanar therapy in real-life patients with rheumatoid arthritis [abstract]. Arthritis Rheum. 2010; 62 Suppl 10:1811

90. Salazar JC, Correa JC, Santos-Moreno P, et al. Cost-utility and costbenefit of biological treatments for rheumatoid arthritis in Colombia. Ann Rheum Dis. 2011;70(Suppl3):203. Available at: http://www. abstracts2view.com/eular/view.php?nu=EULAR11L_THU0070.

91. Yoshida WB. Studies on biosimilar medications. J Vasc Bras. 2010; 9:141-144.

92. Azevedo VF. Are we prepared to prescribe biosimilars? Rev Bras Reumatol. 2010;50:221-224.

93. Azevedo VF, Felippe LR, Machado DM. Opinion of some Brazilian rheumatologists about biosimilars. Rev Bras Reumatol. 2011;51:667-671.

94. Saavedra SI, Quiñones SL. Intercambiabilidad de medicamentos de origen biológico (biofármacos): consideraciones acerca de la aprobación de formulaciones biosimilares (biogenéricos) en Chile. Rev Med Chile. 2006;134:1583-1588.

95. Declaración de la Sociedad Chilena de Reumatología frente a la autorización otorgada por el Instituto de Salud Pública (ISP) de medicamentos biosimilares. Rev Chil Reumatol. 2010;26:218-219.

96. Matar P. Biofármacos y biosimilares. Rev Argent Reumatol. 2009;20: 8-9.

97. DeSanVicente-Célis Z, Salazar JC, Pineda-Tamayo R, Anaya JM. Sobre la necesidad de la farmacoeconomía. Rev Colomb Reumatol. 2011;18:187202. Available at: http://www.scielo.org.co/scielo.php?script=sci_ pdf\&pid=S0121-81232011000300005\&lng=en\&nrm=iso\&tlng=es. 
98. Machado J, Moncada JC, Pineda R. Perfil de utilización de los antifactor de necrosis tumoral en pacientes de Colombia. Biomedica. 2011;31:250-257.

99. World Bank. GDP per capita (current US\$), 2009. Available from: http:// search.worldbank.org/quickview?name $=\mathrm{GDP}+$ per + capita $+\% 28$ curre nt+US\%24\%29\&id=NY.GDP.PCAP.CD\&type=Indicators\&cube_no= 2\&qterm $=$ gros + domestic + product. Accessed June 25, 2012.

100. [No author listed.] Biotecnológicos tienen 'reventado' al Fosyga. Portafolio. 2012. Available from: http://www.portafolio.co/negocios/ biotecnologicos-10-veces-mas-caros-aqui-que-reino-unido. Accessed July 10, 2012.

101. Lara R. Escandaloso monopolio. El Espectador. 2012. Available from: http://www.elespectador.com/impreso/opinion/columna-325355escandaloso-monopolio. Accessed July 10, 2012.
102. Zerda A. TLC atenta contra investigación e innovación. UN Periodico. 2012. Available from: http://www.unperiodico.unal.edu.co/dper/ article/tlc-atenta-contra-investigacion-e-innovacion.html. Accessed July 9, 2012.

103. Ministerio de Comercio, Industria y Turismo. Capítulo 16: Derechos de propiedad intelectual - Artículo 16.9: Patentes. 2012. https://www. mincomercio.gov.co/tlc/publicaciones.php?id=727. Accessed July 12, 2012.

104. Mysler E, Scheinberg M. Biosimilars in rheumatology: a view from Latin America. Clin Rheumatol. 2012;31:1279-1280.
Biosimilars

\section{Publish your work in this journal}

Biosimilars is an international, peer-reviewed, open access journal focusing on the manufacture, development and medicinal use of biopharmaceutical compounds considered similar to an innovator agent. Specific topics covered in the journal include: Regulatory issues and pathways; manufacturing processes; chemical composition and

Submit your manuscript here: http://www.dovepress.com/biosimilars-journal

\section{Dovepress}

structure; quality and purity; patent issues; bioequivalence and interchangeability; clinical efficacy data; patient perspectives. The manuscript management system is completely online and includes a very quick and fair peer-review system. Visit http://www.dovepress.com/ testimonials.php to read real quotes from published authors. 